\title{
Fasting Pancreatic Glucagon in Jamaican Children during Malnutrition and Subsequent Recovery
}

\author{
H. M. PAYNE ROBINSON ${ }^{(59)}$ AND ANNE SEAKINS \\ Tropical Metabolism Research Unit, University of the West Indies, Mona, Kingston, Jamaica
}

\begin{abstract}
Summary
Fasting pancreatic glucagon was observed in Jamaican infants during malnutrition and subsequent recovery. Rehabilitation in two groups of children with isocaloric diets rich either in carbohydrate or fat produced no differences in the rate of weight gain. During malnutrition, plasma pancreatic glucagon concentration was $104 \pm 11(n=20) \mathrm{pg} / \mathrm{ml}$ (mean \pm S.E.) significantly lower than during recovery when the maximum value was $180 \pm 24$ ( $n$ $=13) \mathrm{pg} / \mathrm{ml}$ during the later recovery phase. After clinical recovery glucagon levels declined to $127 \pm 13(n=15) \mathrm{pg} / \mathrm{ml}$. Plasma insulin followed a similar pattern, increasing significantly during catch-up growth and declining after recovery. Slower rates of growth were associated with the simultaneous decline in the concentrations of both hormones after clinical recovery.
\end{abstract}

\section{Speculation}

Low pancreatic glucagon and insulin levels in protein energy malnutrition are adaptive mechanisms to conserve tissue by reducing anabolic and catabolic processes. The increases in hormone concentrations during recovery reflect the increased metabolism associated with growth, and the anabolic actions of insulin dominates glucagon action to promote new tissue synthesis and dramatic increases in weight gain.

The metabolic regulation of energy production undergoes major alterations during protein energy malnutrition (PEM). Protein energy malnutrition is characterised by deficits in total body fat, total body protein, and reduced hepatic and muscle glycogen stores $(3,31)$, and develops after prolonged feeding a diet low in total energy and protein $(32,40)$. With nutritional deprivation, endogenous sources of energy are mobilized. Antecedent diet affects body composition and hence the availability of endogenous energy sources $(15,31)$. Both insulin and glucagon are two major hormones that control endogenous fuel supply $(1,4,13,14,16,19$, $22,30,52,53$ ), insulin-inducing anabolic effects, modulated by the potent glycogenolytic, gluconeogenic, lipolytic, and protein catabolic actions of glucagon $(1,4,14,15,16,17,18,19,21,35,46,47$, $48,49,52,53)$. Although the evidence is indisputable that plasma insulin levels are low in PEM $(6,7,12,29,36,41,42,50)$ little is known about the status of glucagon in malnourished infants. The physiologic and hormonal spectrum of prolonged starvation (1, $14,15,34,51)$ may be compared with that of severe malnutrition, although it is not known whether the requirement for glucagon is the same in starvation as in malnutrition.

This study was designed to examine the effect of preceding diet and nutritional status on fasting plasma glucagon levels in severely malnourished Jamaican infants who were subsequently rehabilitated on one of two high energy diets known to promote rapid weight gain $(19,20,25)$. Plasma insulin, growth hormone, and glucose levels were measured simultaneously because these are known to be interrelated with pancreatic glucagon in various physiologic states.

\section{MATERIALS AND METHODS}

Subjects and dietary treatment. Twenty children with severe protein energy malnutrition were included in this study. Their ages ranged from 6-20 months (median 12) and their \% expected weight for height [Harvard standards (54)] ranged from 52.6-83.6 (median 66.3). Professional review and approval of the proposed investigation was obtained from the Ethics Committee of the University of the West Indies.

During the first 3 or 4 days after admission to the ward, all malnourished children were fed the maintenance diet, calculated to provide sufficient energy and protein without permitting growth. The formula contained dried whole milk, sucrose, and arachis oil in water with a total energy content of $272.3 \mathrm{KJ}$ per $100 \mathrm{ml}$ of feed. (The composition of all the diets is shown in Table 1). During catch-up growth 11 children (Group A) were fed a recovery diet that contained dried whole milk, sucrose, and arachis oil in water with a total energy content of $578.9 \mathrm{KJ} / 100 \mathrm{ml}$. Nine children (Group B) were fed a recovery diet containing dried whole milk, sucrose, and cornstarch in water with a total energy content of $478.8 \mathrm{KJ} / 100 \mathrm{ml}$. Children in groups $\mathrm{A}$ and $\mathrm{B}$ were fed ad libitum until expected weight for height was reached (54). All diets were supplemented with potassium, magnesium, iron, and folic acid. After clinical recovery, each child was given a mixed diet of meat, vegetables, fruit, and milk.

Eight-h fasting blood samples $(6 \mathrm{ml})$ were obtained from the jugular vein at 10 am each morning, once during malnutrition, at weekly intervals during recovery, and once after clinical recovery. During recovery, intervals I, II, III and IV referred to succeeding wk after the onset of high energy feeding, but $\mathrm{V}$ included either 5,6 , or 7 wk of final recovery because the duration of catch-upgrowth varied with each individual child. The blood was collected in two separate tubes as follows (1) containing EDTA $(1 \mathrm{mg} / \mathrm{ml})$ and (2) containing EDTA $(1 \mathrm{mg} / \mathrm{ml})$ and trasylol $(500 \mathrm{KIU} / \mathrm{ml})$. Tube (1) contained blood destined for determinations of plasma insulin, growth hormone, and glucose. Blood in tube (2) was prepared for plasma glucagon determinations. Glucagon was extracted as outlined in the method of Heding (27). The dried extracted glucagon was stored in small stoppered vials at $4^{\circ} \mathrm{C}$ and the plasma separated from tube (1) was stored at $-20^{\circ} \mathrm{C}$ until ready for insulin, growth hormone, and glucose analyses. Eight-h fasting blood samples were obtained from 11 normal adults for glucagon determination.

Analytical methods. All plasma determinations were performed in duplicate. Glucose was determined by the method of Huggett and Nixon (28). Insulin was assayed by the double antibody method of Hales and Randle (26) using reagents supplied in a kit from the Radiochemical Centre, Amersham. The method as recommended in the kit was modified for increased sensitivity in the range $1-25 \mu \mathrm{U} / \mathrm{ml}(31,41,42)$. Growth hormone was assayed by 
Table 1. Carbohydrate, fat, and protein content of maintenance and recovery diets expressed in energy units (KJ/100 ml) and \% of total energy [daily energy intake, $(K J / \mathrm{kg} /$ day)]

\begin{tabular}{|c|c|c|c|c|c|c|c|c|}
\hline & \multicolumn{2}{|c|}{ Carbohydrate } & \multicolumn{2}{|l|}{ Fat } & \multicolumn{2}{|c|}{ Protein } & \multirow{2}{*}{$\begin{array}{c}\begin{array}{c}\text { Total energy } \\
\text { content }\end{array} \\
(\mathrm{KJ} / 100 \mathrm{ml}) \\
\end{array}$} & \multirow{2}{*}{$\begin{array}{l}\text { Energy intake } \\
(\mathrm{KJ} / \mathrm{kg} / \text { day })\end{array}$} \\
\hline & $(\mathrm{KJ} / 100 \mathrm{ml})$ & $\%$ & $(\mathrm{KJ} / 100 \mathrm{ml})$ & $\%$ & $(\mathrm{KJ} / 100 \mathrm{ml})$ & $\%$ & & \\
\hline $\begin{array}{l}\text { Recovery diet A (Dried whole } \\
\text { milk, sucrose, arachis oil, wa- } \\
\text { ter) }\end{array}$ & 180.0 & 31.1 & 346.4 & 59.8 & 52.4 & 9.1 & 578.9 & $\begin{array}{r}625.5- \\
1042.5^{1}\end{array}$ \\
\hline $\begin{array}{l}\text { Recovery diet B (Dried whole } \\
\text { milk, sucrose, cornstarch wa- } \\
\text { ter) }\end{array}$ & 305.2 & 63.7 & 121.2 & 25.3 & 52.4 & 10.9 & 478.8 & $\begin{array}{r}625.5- \\
1042.5^{1}\end{array}$ \\
\hline
\end{tabular}

${ }^{1}$ The recovery diets were fed ad libitum.

a similar double antibody method. The double antibody was obtained from Wellcome Research Laboratories and the iodinated growth hormone from Abbott Laboratories. Growth hormone standard was kindly donated by the National Institute for Medical Research, Medical Research Council, United Kingdom. Glucagon was assayed by a single antibody method (27) using a highly specific antibody (RC S5) for pancreatic glucagon (MW 3500, supplied by Dr. S. Bloom, Royal Postgraduate Medical School, Hammersmith Hospital, London (9)). This species of glucagon is also produced from the alpha cells of the gastric fundus and to a less extent from the duodenum $(45,55,56)$. Enteroglucagon from the cells of the post pyloric gut, (33), which is immunologically and physiochemically distinguishable from pancreatic glucagon, (45) was not being measured. Pork pancreatic glucagon standards and pancreatic $\left[{ }^{125} \mathrm{I}\right]$-glucagon were both supplied by Novo Research Institute, Copenhagen.

Rate of weight change was calculated at the time of blood sampling as an average of the daily weight change expressed per $\mathrm{kg}$ body weight for 4-7 days. Calorie intake was calculated for the same periods. The significance of the difference between means was analysed by students $t$ test.

\section{RESULTS}

There were significant differences in most of the variables measured during malnutrition and subsequent recovery. During malnutrition, fasting pancreatic glucagon, insulin, glucose, and the insulin/glucagon ratio were lower than in the recovery phases (Fig. 1). Fasting growth hormone was significantly higher during malnutrition than after the onset of high energy feeding (Fig. 1). A comparison of all variables measured in recovering groups $\mathrm{A}$ and $B$ is shown in Fig. 1. Rate of weight change and energy intake were significantly increased in both groups of recovering children with the highest values in phases I and II, and declined steadily in subsequent phases (Table 2, Fig. 1). Energy intake was higher in Group A than in Group B (Fig. 1), but there was little difference related to diet in the rate of weight change in Groups A and B. There were slightly higher values for Group A in phases I, II, and IV. Fasting pancreatic glucagon increased during the recovery phases in both groups of children but the mean values at each stage were higher in group A children (Fig. 1 and 2). When the values for both groups were pooled, a progressive increase was shown, which declined after clinical recovery (Table 3, Fig. 3). The values for plasma pancreatic glucagon in clinically recovered children were significantly lower than those in normal adults, $163.5 \pm 6 \mathrm{pg} / \mathrm{ml}(\mathrm{A}=11, P<0.01)$. There were gradual increases in insulin levels as recovery progressed, but plasma insulin concentrations were approximately the same in both groups (Figs. 1, 3 , Table 3). Fasting plasma insulin showed trends similar to that of pancreatic glucagon (Fig. 1, Fig. 3). During recovery the insulin/glucagon molar ratio showed a significant increase but the pattern varied in the two groups (Fig. 1). In group A, there was a

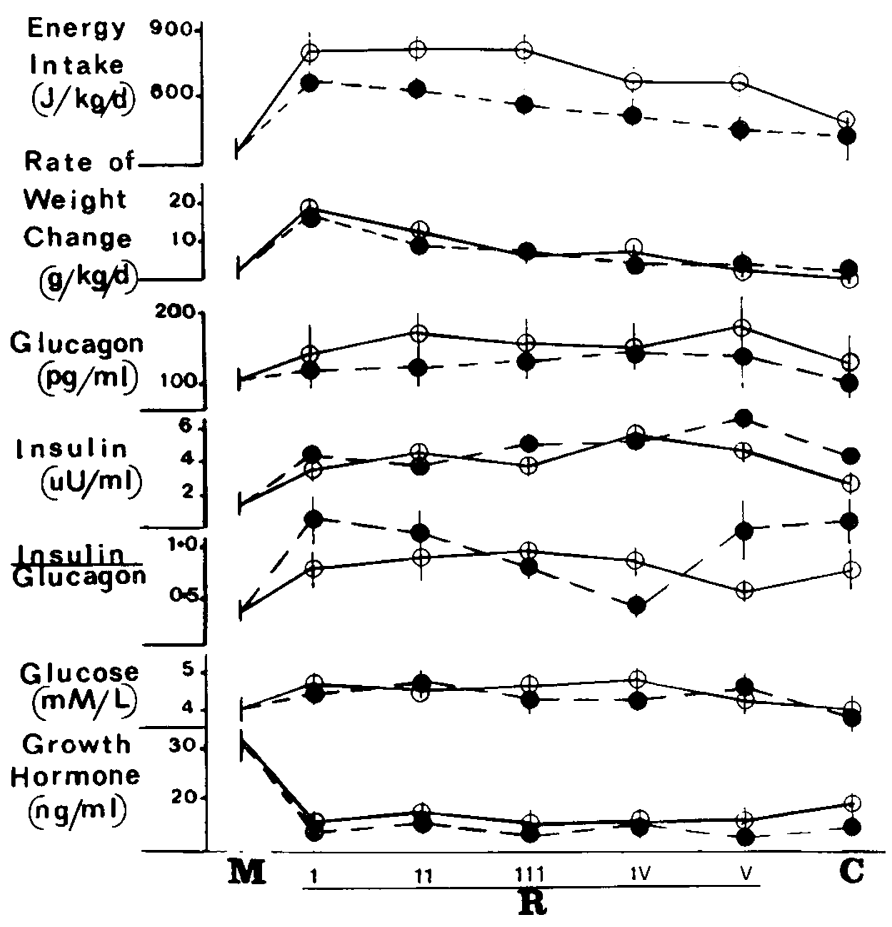

Fig. 1. The effect of Diet A (high fat) and Diet B (high carbohydrate) on energy intake, rate of weight change, fasting plasma concentration of pancreatic glucagon, insulin, glucose and growth hormone, and the insulin/glucagon molar ratio during recovery from protein energy malnutrition. Results from children on Diet $A$ are shown in open circles (-O-) and those from children on Diet B are shown in closed circles (-) - In $\mathrm{C}$, all children were on mixed diet. $\mathrm{M}$ refers to malnutrition, $\mathrm{R}$ to the recovery period, and C to clinical recovery. Phases I, II, III, and IV are the first 4 wk of recovery. Phase $\mathrm{V}$ includes 1,2 , or 3 wk of the final recovery phase. Results are shown as mean \pm S.E.

gradual increase through phases I, II, and III and a decline in the later phases (Fig. 1). In group B, there was a significant increase in phase I which declined steadily in phases II, III, and IV. In phase $\mathrm{V}$ and after clinical recovery, the insulin/glucagon ratio again increased significantly (Fig. 1). When the values for both groups were pooled, the insulin/glucagon ratio showed a significant rise in phases I and II (Table 3). This initial rise was more than 2-fold and steadily declined through phases II, III, and IV, but rose in phase V. After clinical recovery the insulin/glucagon ratio declined (Table 3). Plasma glucose rose slightly during recovery and decreased after recovery, but there were no differences between the two groups (Fig. 1, Table 3). Plasma growth hormone was significantly decreased during and after clinical recovery in both groups (Fig. 1, Table 3). 
Table 2. Rate of weight change and energy intake in malnourished $(M)$, recovering $(R)$ and clinically recovered $(C)$ children. The $R$ phase has been subdivided into time intervals $I, I I, I I I, I V$, and $V^{1}$ and the values for groups $A$ and $B$ are pooled.

\begin{tabular}{|c|c|c|c|c|c|c|c|}
\hline & Malnourished (M) & \multicolumn{5}{|c|}{ Recovering phase $(\mathrm{R})$} & $\begin{array}{l}\text { Clinically } \\
\text { recovered }(\mathrm{C})\end{array}$ \\
\hline $\begin{array}{l}\text { Energy intake } \\
(\mathrm{KJ} / \mathrm{kg} / \text { day })\end{array}$ & $\begin{array}{c}326 \pm 32.9 \\
(14)\end{array}$ & $\begin{array}{c}728 \pm 47 \\
(20)\end{array}$ & $\begin{array}{c}750 \pm 25 \\
(20)\end{array}$ & $\begin{array}{c}715 \pm 38 \\
(17)\end{array}$ & $\begin{array}{l}644 \pm 62.1 \\
\quad(12)\end{array}$ & $\begin{array}{c}585 \pm 41 \\
(12)\end{array}$ & $\begin{array}{c}523 \pm 39 \\
(18)\end{array}$ \\
\hline $\begin{array}{l}\text { Rate of weight change } \\
(\mathrm{g} / \mathrm{kg} / / \text { day })\end{array}$ & $\begin{array}{l}0.60 \pm 0.93 \\
\quad(14)\end{array}$ & $\begin{array}{l}18.28 \pm 1.24^{2} \\
(20)\end{array}$ & $\begin{array}{c}10.59 \pm 1.15^{2} \\
(20)\end{array}$ & $\begin{array}{c}8.18 \pm 1.21^{2} \\
(17)\end{array}$ & $\begin{array}{l}5.68 \pm 1.00^{2} \\
\quad(12)\end{array}$ & $\begin{array}{c}4.5 \pm 0.71^{2} \\
(12)\end{array}$ & $\begin{array}{c}3.6 \pm 1.0^{2} \\
(18)\end{array}$ \\
\hline
\end{tabular}

${ }^{1}$ Phases I, II, III, and V are weekly intervals. Phase V includes 5,6 , or $7 \mathrm{wk}$ of the final recovery phase.

${ }^{2}$ Mean \pm S.E. compared to $M P<0.01$. Number of studies in parentheses.

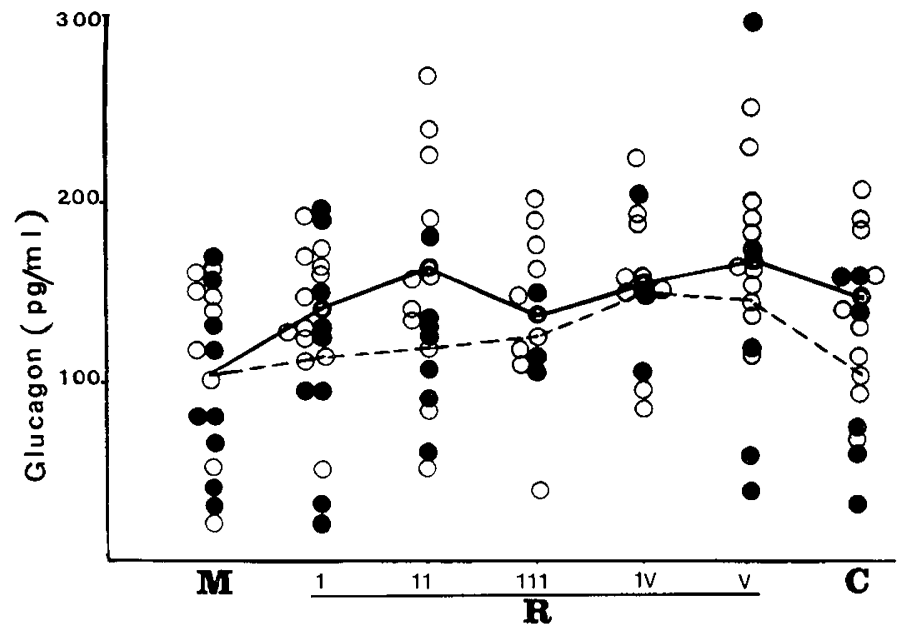

Fig. 2. Fasting pancreatic glucagon concentrations in malnutrition (M), during recovery $(\mathrm{R})$ and after clinical recovery $(\mathrm{C})$. A comparison of the effect of Diet A and Diet B on glucagon levels. Phases I, II, III, and IV are the first 4 wk of recovery. Phase $V$ includes 1,2 , or 3 wk of the final recovery phase. Values from children on Diet $\mathrm{A}$ are shown in open circles $\left(-\mathrm{O}_{-}\right)$. Values from children on Diet B are shown in closed circles (-)In $\mathrm{M}$, all children were on maintenance diet and in $\mathrm{C}$, all children were on mixed diet. The solid line joins the mean values related to Diet $\mathrm{A}$. The broken line joins the mean values related to Diet B.

\section{DISCUSSION}

Brasel (10) states that "data on glucagon secretion in malnutrition are scanty and that none are available in young subjects." Our study supplies this information from malnourished Jamaican infants. We have found that fasting pancreatic glucagon levels, as measured with a highly specific antibody, are low during malnutrition and rise with recovery. After clinical recovery, fasting glucagon levels decline but they are still higher than the levels observed in malnutrition. Fasting plasma insulin follows the same pattern. Our study of hormone concentrations at intervals during recovery has revealed that both glucagon and insulin concentrations rise progressively as body weight increases.

Whether the metabolic adaptations to starvation, associated with changes in hormone concentrations are comparable to the adaptations in protein energy malnutrition is unknown. In some instances there are similar changes in hormone concentrations, as is shown for insulin, levels of which are consistently low in starvation $(11,13,14,15,16,30,31,51)$ and in malnutrition $(5,6$, $7,10,36,41,42)$, which is confirmed in the present study.

The reports of glucagon status in starvation are conflicting. A transient rise in plasma glucagon in the first few days of starvation (1), followed by a steady decline to baseline levels as starvation was prolonged, has been demonstrated $(34,37)$. Evidence of glucagon status in malnutrition has been obtained from experimental rat models. Rats fed for $3 \mathrm{wk}$ on a 5\% lactalbumin diet, known to promote clinical features similar to protein energy

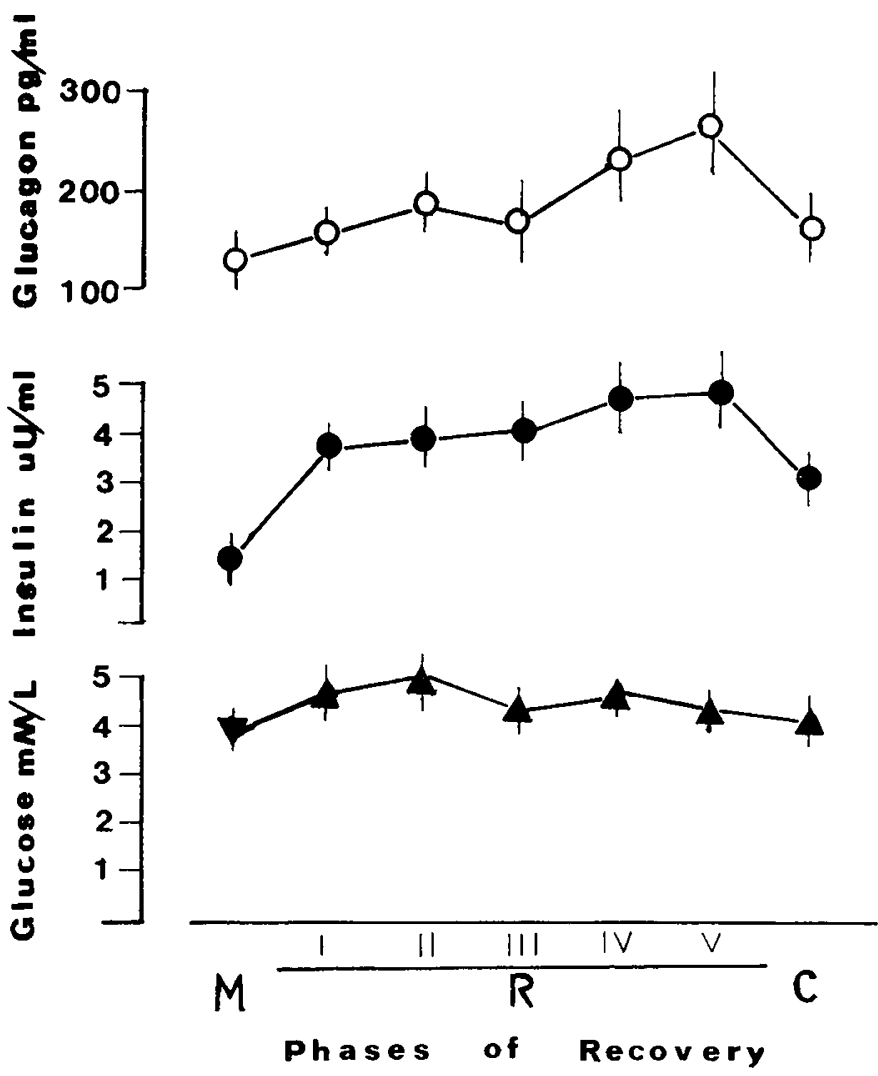

Fig. 3. Fasting pancreatic glucagon, insulin, and glucose in malnourished $(M)$ recovering $(R)$ and clinically recovered $(C)$ children. The first 4 wk of recovery are indicated as I, II, III, and IV. Phase V refers to the final 1, 2, or 3 wk of recovery. Pancreatic glucagon is shown in open circles $(-\mathrm{O})$, insulin in closed circles (-) and glucose in closed triangles $\left(-\boldsymbol{\Lambda}^{-}\right)$. Results are expressed as mean \pm S.E.

malnutrition, demonstrated increased circulating glucagon levels compared with controls (5). These rats demonstrated reduced serum insulin, thyroxine, and corticosterone levels: a hormonal spectrum that does not exactly conform to that of infant malnutrition in which elevated levels of glucocorticoids have been found (2). In spite of differences in the duration and degree of food deprivation, the animal species used, the experimental design, and the variable specificity of the antibody used in the assay for glucagon, there is enough evidence to suggest that glucagon responses in short and long term fasting may be different, and that there is a changing requirement for glucagon with the length of the fast. It seems reasonable to compare our results in infants who have become malnourished after prolonged chronic undernutrition, with the results of prolonged starvation in which a steady decline in peripheral plasma glucagon concentrations have been noted. Our results from malnourished children are in agreement with Marliss et al. (34), and Buchanan et al. (11) who have shown a decrease in pancreatic glucagon levels with starvation. 
Table 3. Eight-h fasting values of plasma glucagon, insulin, insulin/glucagon, glucose, and growth hormone in malnourished (M), recovering $(R)$ and clinically recovered $(C)$ children. $R$ has been subdivided into time intervals $I, I I, I I I, I V$, and $V^{1}$ and the values for groups $A$ and $B$ were pooled.

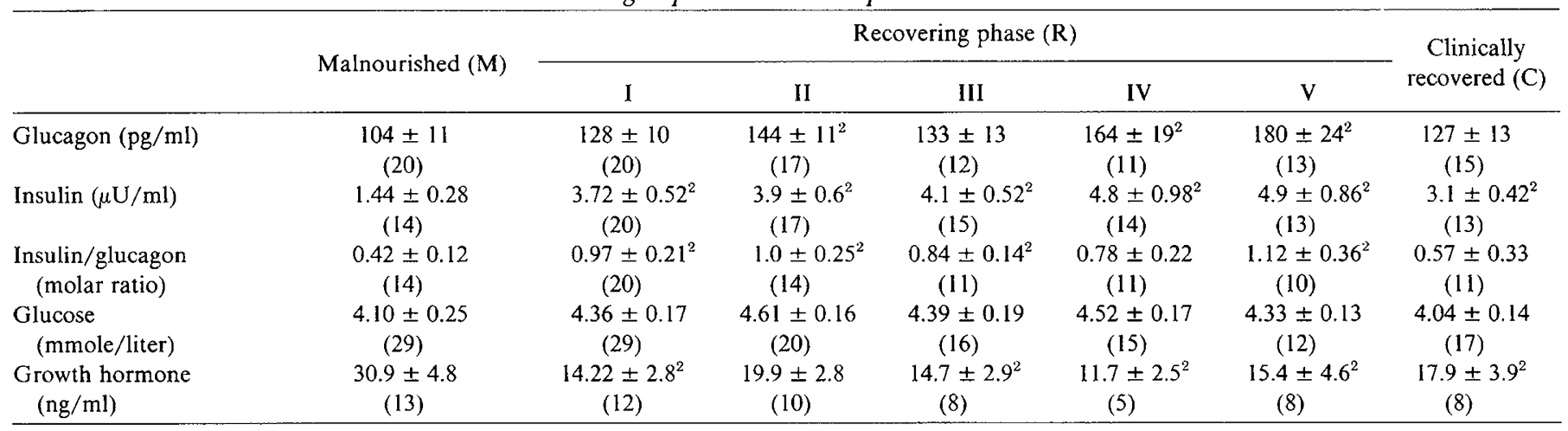

${ }^{1}$ Phases I, II, III, and IV are weekly intervals. Phase V includes 5, 6, or $7 \mathrm{wk}$ of the final recovery phase.

${ }^{2}$ Mean \pm S.E. in I, II, III, IV, and V compared to $M, P<0.01$. Numbers of studies in parentheses.

The recovery diets offered were high energy formulae in which most of the energy was provided either in the form of fat (Diet A) or carbohydrate (Diet B). During this period there were significant increases in metabolic processes resulting in abnormally high rates of weight gain and increased turnover rates (24) particularly in phase I and II of the catch up growth phase. The different intakes did not affect the rates of weight gain with both diets. Plasma pancreatic glucagon tended to be lower in those children fed the high carbohydrate diet than in the other group fed the high fat diet, whereas there were no differences in plasma insulin that could be attributed to a difference in diet. The effect of antecedent diet on hormone responses has been well documented $(38,53)$. High carbohydrate diets have been shown to reduce pancreatic glucagon levels in normal human adults while low carbohydrate diets produce the opposite effect (38). Our results confirm these findings in that, the Diet $B$ group produced less glucagon than the Diet A group. After clinical recovery, a mixed diet containing meat, fruit, vegetables, cereals, and milk was given to each child. The energy intake and rate of weight gain were decreased at this stage. Plasma levels of glucose, glucagon, and insulin also declined. The low insulin/glucagon molar ratio in malnutrition suggests the requirement for reduced anabolism as part of the adaptive mechanism to conserve life in the absence of adequate food. Our finding of high plasma growth hormone concentrations in malnutrition apparently bears no direct relationship to plasma glucagon and insulin levels, although growth hormone has been shown to stimulate both glucagon and insulin release $(8,23,37$, $39,44)$. When the results from each recovery phase were pooled a clear picture emerges. During recovery, there are increases in plasma glucagon and insulin, but the insulin/glucagon ratio in phases I and II when rates of weight gain and energy intake are highest is more than twice that observed in malnutrition. The high insulin/glucagon ratio suggests an increase in anabolic processes, and represents selective protein deposition at this stage which has been shown from energy cost of growth studies (43).

In conclusion, fasting pancreatic glucagon and insulin levels were levels lower during malnutrition than in the subsequent phases of recovery. Low glucagon and insulin levels are clearly an advantage in the reduction of metabolic processes to minimize fuel consumption and to conserve tissue. Both high fat and high carbohydrate diets given during recovery induced rapid rates of weight gain, but plasma glucagon levels were reduced in those children fed a high carbohydrate diet. The increase in metabolic processes during the recovery period was reflected in the high insulin/glucagon ratio which predisposed to increased anabolism by insulin action to stimulate new tissue synthesis and promote growth.

\section{REFERENCES AND NOTES}

1. Aguilar-Parada, E., Eisentraut, A. M., and Unger, R. H.: Effects of starvation on plasma pancreatic glucagon in normal man. Diabetes, 18: 717 (1969).
2. Alleyne, G. A. O. and Young, V. H.: Adrenocortical function in children with severe protein-calorie malnutrition. Clin. Sci., 33: 189 (1967).

3. Alleyne, G. A. O. and Scullard, G. H.: Alteration in carbohydrate metabolism in Jamaican children with severe malnutrition. Clin. Sci., 37: 631 (1969).

4. Alford, F. P., Bloom, S. R., Hall, R., Besser, G. M., Coy, D. H., Kastin, A. J., and Schally, A. V.: Glucagon control of fasting glucose in man. The Lancet, 2: 974 (1974).

5. Anthony, L. E. and Faloona, G. R.: Plasma insulin and glucagon levels in protein malnourished rats. Metabolism, 23 (1): 303 (1974).

6. Baig. H. A. and Edozien, J. C.: Carbohydrate Metabolism in kwashiorkor. Lancet, 2: 662 (1965).

7. Becker, D. J., Pimstone, B. L., Hansen, J. D. L., and Hendricks, S.: Insulin secretion in protein calorie malnutrition. I. Quantitative abnormalities and response to treatment. Diabetes, 20: 542 (1971).

8. Bencosme, S. A., Tsutsumi, V., Martin, J. M., and Akerblom, H. K.: Ultrastructural changes in $\beta$ cells of pancreatic islets from rats with elevated levels of circulating growth hormone secreted by MTT-W15 tumor. Diabetes, 20: 15 (1971).

9. Bloom. S. R.: A specific and sensitive glucagon immunoassay. Diabetologia, 7: 742 (1971).

10. Brasel, J. A.: Endocrine adaptation to malnutrition. Pediatr. Res., 14: 1299 (1980).

11. Buchanan, K. D., Vance, J. I., Aoki, T., and Williams, R. H.: Effect of starvation and refeeding on serum levels of glucagon and insulin. Diabetes, 16: 517 (1967).

12. Buchanan, K. D., Vance, J. E., and Williams, R. H.: Effect of Starvation on Insulin and Glucagon Release from isolated islets of Langerhans of the rat. Metabolism, 18 (2): 155 (1969)

13. Cahill, G. F. Jr.: Famine Symposium. Physiology of acute starvation in man Ecology of Food and Nutrition, 6: 221 (1978).

14. Cahill, G. F. Jr.: Starvation in man. New Engl. J. Med., 282: 668 (1970).

15. Cahill, G. F., Herrera, M. G., Morgan, A. P., Soeldner, J. S., Steinke, J., Levy, P. L., Reichard, G. A., and Kipnis, D. M.: Hormone - fuel interrelationships during fasting. J. Clin. Invest., 45: 1751 (1966).

16. De Duve, C.: Glucose, insuline et diabetic Biochimie, physiologie, pathogenic, applications therapeutiques. Bruxelles, J. Goemaere, Imprimerie (1945).

17. Edwards, J. C. and Taylor, K. W.: Fatty acids and the release of glucagon from isolated guinea-pig islets of Langerhans incubated in vitro Biochim. Biophys. Acta., 215: 310 (1970).

18. Felig, P., Owen, O. E., Wahren. J., and Cahill, G. F. Jr.: Amino acid metabolism during prolonged starvation. J. Clin. Invest., 48: 584 (1969).

19. Foa, P. P.. Galansino, G., and Pozza, G.: Glucagon : A second pancreatic hormone. Rec. Prog. Hormone Research, 13: 1473 (1957).

20. Flores, H., Seakins, A., Brooke, O. G., and Waterlow, J. C.: Serum and liver triglycerides in malnourished Jamaican children with fatty liver. Amer. J. Clin. Nutr., 27: 610 (1974).

21. Foa, P. P.: Glucagon. Ergebh. Physiol., 60: 141 (1968).

22. Gerich, J., Cryer, P., and Rizza, R.: Hormonal mechanisms in acute glucose counterregulation: The relative roles of glucagon, epinephrine, norepinephrine, growth hormone, and cortisol. Metabolism, 29 (11) (Suppl. I): 1128 (1980).

23. Gerich, J. E., Charles, M. A., and Grodsky, G. M.: Regulation of pancreatic insulin and glucagon secretion. Annual Review of Physiol., 38: 353 (1976).

24. Golden, M. H. N., Waterlow, J. C., and Picou, D.: Protein turnover, synthesis and breakdown before and after recovery from protein-energy malnutrition. Clin. Sci. Mol. Med., 53: 473 (1977).

25. Golden, B. E. and Golden, M. H.: Plasma zinc, rate of weight gain, and the energy cost of tissue deposition in children recovering from severe malnutrition on a cow's milk or soya protein based diet. Amer. J. Clin. Nutr., 34: 900 (1981).

26. Hales, C. N. and Randle, P. J.: Immunoassay of insulin with insulin-antibody precipitate. Biochem. J., 88: 137 (1963).

27. Heding, L. G.: Radioimmunological determination of pancreatic and gut glucagon in plasma. Diabetologia, 7: 10 (1971).

28. Hugget, A. S. and Nixon, D. A.: Use of glucose oxidase, peroxidase and o- 
dianisidine in the determination of blood and urinary glucose. Lancet, 2: 368 (1957).

29. James, W. P. T. and Coore, H. G.: Persistent impairment of insulin secretion and glucose tolerance after malnutrition. Am. J. Clin. Nutr., 23: 386 (1970).

30. Joost, H. G. and Beckman, J.: On the relation of glucose and insulin secretion in the fasting state. Metabolism, 29 (l): 23 (1980).

31. Kerr, D. S., Stevens, M. C. G., and Robinson, H. M.: Fasting metabolism in infants. I. Effect of severe undernutrition on energy and protein utilization. Metabolism, 27 (4): 411 (1978)

32. Landman, J. and Jackson, A.: The role of protein deficiency in the aetiology of kwashiorkor. West Indian Med. J., XXIV: 229 (1980).

33. Makman, M. H. and Sutherland, F. W. Jr.: Use of liver adenylcyclase for assay of glucagon in human gastro-intestinal tract and pancreas. Endocrinology, 75 : 127 (1964).

34. Marliss, E. B., Aoki, T. T., Unger, R. H., Soeldner, J. T., and Cahill, G. F. Jr. Glucagon levels and metabolic effects in fasting man. J. Clin. Invest., 49: 2256 (1970).

35. Miller, L. L.: Glucagon: a protein catabolic hormone in the isolated perfused rat liver. Nature (London), 185: 248 (1960).

36. Milner, R. D. G.: Metabolic and hormonal responses to glucose and glucagon in patients with infantile malnutrition. Pediatr. Res., 5: 33 (1971).

37. Muller, W. A.. Aoki, T. T., and Cahill, G. F. Jr.: Effect of alanine and glycine on glucagon secretion in postabsorptive and fasting obese man. J. Clin. Endocrinol. Metab., 40: 418 (1975).

38. Muller, W. A., Faloona, G. R., and Unger, R. H.: The influence of antecedent diet upon glucagon and insulin secretion. New Engl. J. Med., 285: 1450 (1976)

39. Pierluissi, J., Pierluissi, R., and Ashcroft, S. J. H.: Effects of Growth Hormone in Insulin Release in the rat. Diabetologia, 19:39l (1980).

40. Rhodes, K.: In: Protein malnutrition-Proc. of a conference in Jamaica. Ed. J. C. Waterlow. p 34 (University Press, Cambridge, 1953).

41. Robinson, H. and Picou, D.: A comparison of fasting plasma insulin and growth hormone concentrations in marasmic, kwashiorkor, marasmic-kwashiorkor and underweight children. Pediatr. Res., 11: 637 (1977).

42. Robinson, H. M. P., Cocks, T., Kerr, D., and Picou, D.: Hormonal control of weight gain in infants recovering from protein energy malnutrition I. The effect of insulin and metabolic rate. Pediatr. Res., I4: 28 (1980).

43. Robinson. H., Golden, M., and Jackson, A.: Insulin and the energy cost of growth during recovery from protein energy malnutrition. 24th Scientific meeting of the Commonwealth Caribbean Medical Research Council P 54 (1979).

44. Robinson, H. M. and Wilson, M. B.: The effect of growth hormone on insulin release from isolated rabbit islets. International Diabetes Congress, New Delhi,
India (1976).

45. Sasaki, H., Faloona, G. R., and Unger, R. H.: Enteroglucagon. Prog. in Gastroenterology, 67 (4): 746 (1974)

46. Schade, D. S. and Eaton, R. P.: Modulation of fatty acid metabolism by glucagon in man. I. Effects in normal subjects. Diabetes, 24 (5): 502 (1975).

47. Schade, D. S. and Eaton, R. P.: Modulation of fatty acid metabolism by glucagon in man. II. Effects in insulin-deficient diabetics. Diabetes, 24 (5): 510 (1975).

48. Sokal, J. E., Sarcione, E. J., Henderson, A. M.: Relative potency of glucagon and epinephrine as hepatic glucogenolytic agents : studies with the isolated perfused rat liver. Endocrinology, 74: 930 (1964).

49. Sokal, J. E.: Glucagon-an essential hormone. Amer. J. Med., 41: 331 (1966)

50. Kabadi, U. M., Eisenstein, A. B., and Strack, I.: Decreased plasma insulin, but normal glucagon in rats fed low protein diets. J. Nutrition, 106 (9): 1247 (1976).

51. Unger, R. H., Eisentraut, A. M., and Madison, L. L.: The effects of total starvation upon the levels of circulating glucagon and insulin in man. J. Clin. Invest., 42: 1031 (1963)

52. Unger, R. H.: Glucagon physiology and pathophysiology. N. Engl. J. Med., 285: 443 (1971).

53. Unger, R. H. and Lefebre, P. J.: Glucagon Physiology. In: P. J. Lefebre, Ed. and R. H. Unger, Ed.: Glucagon molecular physiology. Clinical and therapeutic implications p 213. (Pergamon Press, New York, New York, 1972).

54. Vaughan. V. C.: Developmental pediatrics. Growth and development. In: W. E. Nelson, V. C. Vaughan, and R. J. McKay: Textbook of Pediatrics p. 15 (W. B Saunders. Co., Philadelphia, 1969).

55. Vranic, M., Pek, S., and Kawari, R.: Increased "glucagon immunoreactivity in plasma of totally depancreatized dogs." Diabetes, 23: 905 (1974).

56. Valverde, I., Dobbs, R., and Unger, R. H.: Heterogeneity of plasma glucagon immunoreactivity in normal, depancreatized and alloxan-diabetic dogs. Metabolism, 24 (9): 1021 (1975).

57. The authors thank the nursing staff of the Tropical Metabolism Research Unit for their meticulous care of these infants, to Ailsa Clarke for excellent technical assistance and to Evadne Forrest for typing the manuscript. The author gratefully acknowledge the constructive criticism and advice provided by Michael Golden.

58. We are indebted to Dr. S. Bloom who kindly donated the pancreatic glucagon antibody which was used in the first series of experiments.

59. Requests for reprints should be addressed to: Dr. Hazel M. Payne Robinson, Tropical Metabolism Research Unit, University of the West Indies, Mona, Kingston 7, Jamaica.

60. Received for publication April 1, 1981.

61. Accepted for publication March 19, 1982.

\section{ANNOUNCEMENT}

Title: Sixth Annual Continuing Education Pediatric Update

Place: Rose Hall Intercontinental Resort, Jamaica

Dates: January 27-February 5, 1983

Scope: An Excellent Educational Program Combining Clinically Oriented Information and Innovative Approaches to Areas of Medical Practice and Research

Contact Person: Dr. Harold Lubin

(614) 461-2680 